\title{
PEMETAAN DAN PRODUKSI BIOMASA TUMBUHAN PAKAN LOKAL DI PROVINSI BALI
}

\author{
SUARNA, I W., M. A. P. DUARSA, A. A. A. S. TRISNADEWI, \\ N. N. CANDRAASIH K., DAN I W. WIRAWAN \\ Pusat Penelitian dan Pengembangan Tumbuhan Pakan Universitas Udayana \\ e-mail : wynsuarna@unud.ac.id
}

\begin{abstract}
ABSTRAK
Tumbuhan pakan ternak (TPT) memiliki peran yang sangat strategis dengan semakin meningkatnya kebutuhan hijauan untuk peningkatan produktivitas ternak ruminansia. Berbagai jenis TPT lokal dan introduksi memiliki kualitas yang sangat baik dan berpotensi sebagai konsentrat hijau. Berdasarkan hal tersebut sangat diperlukan sebuah penelitian yang bertujuan untuk memetakan dan menghitung produksi biomasa TPT lokal di Provinsi Bali. Penelitian menggunakan metode survei di 190 unit lahan. Unit lahan disusun dengan metode tumpang tindih dari peta jenis tanah, peta tata guna lahan, dan peta iklim. Hasil penelitian menunjukkan bahwa terdapat perbedaan potensi dan karakteristik tumbuhan pakan pada berbagai kondisi iklim, tataguna lahan dan jenis tanah. Kawasan dengan tipe iklim D, E, dan F banyak didominasi oleh rumput-rumputan jenis Heteropogon contortus, Botriochloa, Themeda, Polytrias, dan rumput Hyparhenia rupa. Produksi hijauan rata-rata dari tumbuhan yang tergolong pastura alami adalah 214,11 kg DM ha-1 dengan kontribusi utama adalah rumput Paspalum conyugatum dan Cynodon dactilon masing-masing sebesar 20,99\% dan 8,60\%. Rata-rata produksi pada kebun hijauan, semak, pohon, dan tumpang sari berturut-turut adalah: 871,11 $\mathrm{kg} \mathrm{DM} \mathrm{ha}^{-1}, \mathrm{o}, 88 \mathrm{~kg} \mathrm{DM}_{\text {pohon }}{ }^{-1}, 2,10 \mathrm{~kg}$ DM pohon ${ }^{-1} 151,2$ $\mathrm{kg} \mathrm{DM} \mathrm{ha-1}$. Untuk hijauan pohon kontribusi terbesar dan daya adaptasinya paling baik adalah tanaman gamal (Gliricidia sepium). Produksi biomassa hijauan pakan di Bali mencapai 476.057,27 ton dan simpanan karbonnya mencapai 223.746.92 ton. Dapat disimpulkan bahwa TPT lokal memiliki keberagaman dan perbedaan yang spesifik pada berbagai kawasan di Provinsi Bali, serta produksi biomasa yang tinggi berperan penting dalam mitigasi perubahan iklim.
\end{abstract}

Kata kunci: TPT lokal, tata guna lahan, produksi biomasa, pemetaan

\section{MAPPING AND PRODUCTION OF LOCAL FORAGE BIOMASS PLANT IN BALI PROVINCE}

\begin{abstract}
Tropical forage has very strategic role due to the increasing need of forage to increase the productivity of ruminants. Several types of local and introduced forage plants have excellent quality and potential to applied as green concentrates. Based on those, a research is needed to map and calculate the production of local tropical forages biomass in Bali Province. The study used survey methods in 190 land units. Land units are prepared using overlapping method from soil type maps, land use maps, and climate maps. The results showed the differences in the potential and characteristics of local forage plants in various climatic conditions, land use and soil types. Areas with climate types D, E, and F are dominated by grass species such as Heteropogon contortus, Botriochloa, Themeda, Polytrias, and Hyparhenia rupa. The average forage production of plants classified as natural pastures was $214.11 \mathrm{~kg} \mathrm{DM} \mathrm{ha}^{-1}$ with the main contribution being Paspalum conyugatum and Cynodon dactilon each at $20.99 \%$ and $8.60 \%$. The average production in forage, bush, tree, and intercropping were respectively: $871.11 \mathrm{~kg}$ $\mathrm{DM} \mathrm{ha}^{-1}, 0.88 \mathrm{~kg}$ DM tree ${ }^{-1}, 2.10 \mathrm{~kg}$ DM tree ${ }^{-1} 151.2 \mathrm{~kg} \mathrm{DM} \mathrm{ha}^{-1}$. The tree species with the largest yield for forage and had the best adaptability is Gliricidia sepium. The production of forage biomass in Bali reached 476,057.27 tons and its carbon storage reached 223,746.92 tons. It can be concluded that the diversity of tropical forages has their own adaptability and perform a particular distribution among various regions in Bali. The diversity of local forage species also produced high biomass which plays an important role in climate change mitigation.
\end{abstract}

Keywords: local forage, land use, biomass production, mapping 


\section{PENDAHULUAN}

Bali memiliki berbagai jenis ternak pemakan hijauan (ruminansia) yang sangat terkenal dan menjadi komuditas unggulan tetapi beberapa jenis ternak diantaranya populasinya sudah mengalami tekanan. Salah satu ternak ruminansia yang menjadi komuditas unggulan Provinsi Bali adalah ternak sapi bali. Pengembangan peternakan sapi bali di Bali memiliki beberapa tujuan strategis yakni: untuk melestarikan dan mengembangkan kekayaan plasma nutfah Bali, mengurangi kemiskinan dan pengangguran, dan meningkatkan kesejahteraan masyarakat. Agar tercapai tujuan tersebut diperlukan upaya-upaya yang sangat sistematis dan berkelanjutan sehingga performan sapi bali dapat ditingkatkan. Usaha peternakan sapi bali di Bali khususnya dan di Indonesia pada umumnya sebagian besar (99\%) adalah usaha peternakan rakyat dengan skala usaha 1-4 ekor per rumah tangga peternak (Disnak Bali, 2010). Pengembangan peternakan sapi di Bali saat ini dihadapkan pada berbagai permasalahan yang sangat mempengaruhi produktivitas sapi bali. Dua permasalahan utama yang dihadapi adalah terbatasnya ketersediaan bibit sapi dan terbatasnya ketersediaan pakan baik pakan hijauan maupun konsentrat.

Jika dikaitkan dengan menurunnya pupulasi beberapa jenis ternak ruminansia di atas maka harus diciptakan sebuah strategi untuk melindungi dan mengembangkan polulasi ternak serta meningkatkan produktivitasnya. Salah satu upaya yang dapat dilakukan adalah dengan menyediakan hijauan pakan yang berkualitas dan berkecukupan (Ginantra et al., 2014). Berkenaan dengan hal tersebut maka sangat diperlukan sebuah studi untuk mengenal lebih dekat karakteristik, potensi dan distribusi tumbuhan pakan yang ada di Provinsi Bali sehingga dapat ditemukan kapasitas daya dukung dan daya tampung lahan dalam memasok hijauan pakaan sehingga dapat menyediakan hijauan pakan yang cukup dan berkualitas.

Seminar nasional HITPI (Himpunan Ilmuwan Tumbuhan Pakan Indonesia) telah mengamanatkan bahwa tumbuhan pakan yang ada di Indonesia perlu dikaji dan diidentifikasi dengan cermat sehingga dapat ditemukan tumbuhan pakan mana yang sangat potensial dikembangkan dan dilakukan sentuhan teknologi sehingga memiliki potensi produksi dengan kualitas menyamai konsentrat (Suarna dan Suryani, 2013). Suatu langkah penting yang harus dilakukan adalah melakukan pemetaan terhadap distribusi dan habitasi tumbuhan pakan ternak (TPT) lokal serta mencermati kemampuan produksi biomassa TPT sehinga menjadi informasi awal untuk mendapatkan jenis TPT lokal yang unggul. Pemetaan itu juga memberikan informasi tentang luasan tutupan vegetasi oleh TPT sehingga dapat dipergunakan sebagai dasar perhitungan untuk mitigasi terhadap perubahan iklim.

\section{METODE PENELITIAN}

Dalam rancangan survei lapangan, pulau Bali dibagi menjadi 5 daerah iklim, 7 jenis tanah dan 5 jenis penggunaan lahan. Ketiga faktor ini sangat besar pengaruhnya terhadap penyediaan hijauan pakan. Dengan demikian pengambilan sampel didasarkan atas ketiga faktor tersebut. Untuk mencerminkan penyediaan hijauan selama setahun, maka sampel akan diambil sebanyak dua kali yakni pada musim hujan dan musim kemarau. Jenis penggunaan lahan dibedakan menjadi 5 jenis yakni: kebun/perkebunan, sawah irigasi, sawah tadah hujan, semak, dan tegalan/ladang.

Kombinasi dari ketiga faktor (iklim, jenis tanah, dan lahan) adalah 5 (daerah iklim) $\times 7$ (jenis tanah) $\times 5$ $($ penggunaan lahan $) \times 2($ frekuensi pengambilan $)=350$ kombinasi. Luasan areal minimal yang diambil sebagai sampel lokasi adalah 10 ha, sehingga dapat diperoleh 190 kombinasi sebagai unit lahan pengambilan sampel. Setiap lokasi diambil minimal 5 sampel sehingga jumlah sampel adalah 950 sampel. Pengambilan sampel menggunakan kuadrat berukuran $50 \times 50 \mathrm{~cm}$ sesuai metode pengukuran the dry weight rank method menurut t'Mannetje and Haydock (1963).

Penentuan lokasi sampel terkait dengan desa sampling ditentukan berdasarkan purposive random sampling, sehingga sampel yang diambil mewakili faktor iklim, jenis tanah, dan macam penggunaan lahan sesuai dengan unit lahan yang dibuat. Kombinasi ketiga factor tersebut menyebabkan terjadinya interseksi (irisan) antara desa yang satu dengan desa yang lainnya, sehingga wilayah yang dijadikan sampel menggunakan nomor dengan luasan minimal 10 ha.

\section{HASIL DAN PEMBAHASAN}

Perbedaan topografi, geografi, dan klimatologis suatu daerah memberikan penampilan jumlah dan jenis vegetasi yang berbeda. Perbedaan tersebut juga menyebabkan terjadinya perbedaan aktivitas dan dominansi spesies yang berbeda pada masing-masing lokasi riset di Provinsi Bali (Kusumadewi et al. 2015). Selain ketiga faktor di atas perbedaan tersebut juga disebabkan oleh perbedaan tata guna lahan pertanian serta masih belum mantapnya keberpihakan petani terhadap upaya penyediaan hijauan pakan di Indonesia (Suarna et al., 2014).

As-Syakur et al. (2011) telah melakukan pemetaan terhadap beberapa jenis komoditas tanaman pakan dengan mengaplikasikan metode penginderaan jarak jauh (remote sensing). Tanaman pakan yang dipetakan 
kesesuaian iklimnya adalah rumput gajah (Pennisetum purpureum SCHUM.), Setaria (Setaria spachelata), kelompok Leguminosa, Sorgum (Shorgum bicolor), gandum (Triticum aestivum), jagung (Zea mays), dan ubi kayu (Manihot utilissima). Peta kesesuaian beberapa komoditas tanaman pakan tersebut hanya dilihat dari segi iklim. Sebaran kesesuaian lahan beberapa komoditas tanaman pakan di Provinsi Bali berbeda termasuk kerentanannya terhadap tekanan perubahan iklim.

Penyebaran berbagai spesies tumbuhan akan dibatasi oleh kondisi iklim dan tanah serta daya adaptasi dari masing-masing spesies tumbuhan tersebut. Hubungan antara iklim dan tumbuhan adalah hubungan yang saling pengaruh. Selain iklim dapat mempengaruhi pertumbuhan dan perkembangan tanaman, keberadaan vegetasi juga dapat mempengaruhi iklim disekitarnya. Semakin besar total biomass yang terlibat dan semakin ekstensif penyebarannya, maka akan semakin nyata pengaruhnya terhadap iklim wilayah tersebut. Peran vegetasi mirip dengan peran bentangan air. Hal tersebut disebabkan karena tumbuhan mengandung banyak air dan tumbuhan menyumbang banyak uap air ke atmosfer melalui proses transpirasi (Lakitan, 2002). Setiap tanaman memiliki kebutuhan terhadap faktor tumbuh optimal yang berbeda. Perbedaan keberagaman jenis tumbuhan pada berbagai tata guna lahan yang ditemukan dalam penelitian ini disebabkan oleh perbedaan intervensi dan perlakuan manusia pada saat melakukan pengelolaan dan pengolahan terhadap lahan garapannya (Suarna et al, 2016) Keberagaman tumbuhan pakan di berbagai kawasan ternaung seperti di bawah pohon kelapa sawit dan di bawah pohon kelapa telah diungkapkan pula berturut-turut oleh Taufan et al. (2014) dan Artise dan Elly (2014). Keberagaman dan adanya spesies yang spesifik pada berbagai tempat terbuka seperti pada padang penggembalaan alami, sabana, padang penggembalaan kuda pacuan juga disebutkan oleh Suhubdy (2013) dan Sudirman et al. (2014).

Di Bali Barat bagian Utara, yang meliputi kecamatan Gerokgak antara lain di Desa Sumberkimo, Pemuteran, Penyabangan, Tukad Sumaga, dan Celukan Bawang hijauan pakan didominasi oleh: Hyparrhenia rufa, Paspalum comersonii, Arthraxon hispidus, Bothriochloa pertusa, Botriochloa ischaenum, Brachiaria reptans, Commolena diffusa, Crotalari anagiroides, Cynodon dactylon, Desmanthus virgatus, Eleusin indica, Imperata cylindrica, Oplismenus burmannii, Orysa sativa, Diplazium esculentum, Paspalum conjugatum, dan Themeda arguens.

Di bagian selatan Bali Barat antara lain di Desa Gilimanuk, Melaya, Tuwed, Mendoyo Dauh Tukad (Gambar 1) vegetasi tumbuhan pakan didominasi oleh:
Alysicarpus vaginalis, Brachiaria reptans, Imperata cylindrica, Oplismenus burmannii, Centrosema pubescens, Ipomoea reptans, Paspalum conjugatum, Desmodium triflorium, Paspalum conjugatum, Mikania cordata, Sporobolus africanus, Commelina diffusa, Crotalaria junce, dan Cynodon dactylon.

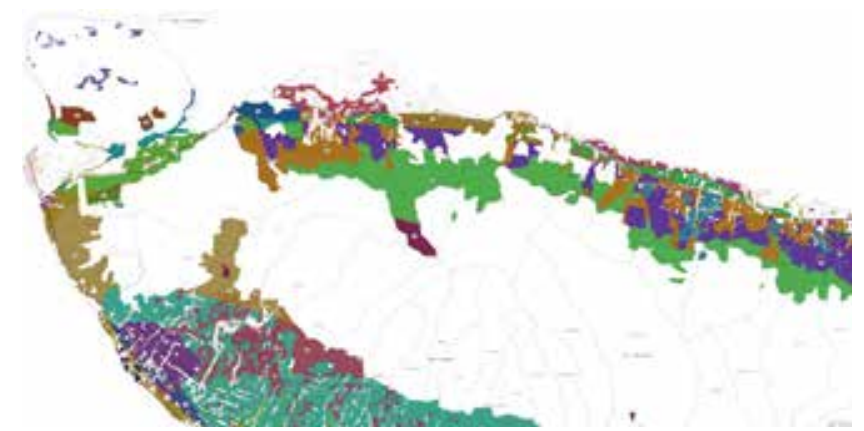

Gambar 1. Hamparan vegetasi TPT di Bali Bagian Barat

Di Bali Utara Bagian Tengah yang meliputi Kecamatan Seririt, Banjar, Busungbiuu, Buleleng, Sawan, Kubu Tambahan, dan Tejakula yang meliputi Desa Tigawasa, Kayu Putih, Temukus, Kaliasem, Anturan, Tukad Mungga, Pemaron, Penarukan, Sangsit dan Bungkulan (Gambar 2), vegetasi tumbuhan pakan didominasi oleh: Pennisetum purpureum, Sorghum bicolor, Leucaena leucocephala, Panicum repens, Cynodon dactylon, Lersia hexandra, Commolena diffusa, Commelina diffusa, Digitaria, Axonopus compresus, Polytrias amaura, Bhachiaria, Debelgia satifolia Roxb, Sesbania grandiflora, dam Themeda arguens.



Gambar 2. Hamparan lahan dengan berbagai vegetasi tanaman pakan

Dengan kondisi klimatologis yang berbeda daerah atau desa-desa seperti Wanagiri, Pegayaman, Candikuning, Batunya, Baturiti, Pupuan, dan Pujungan (Gambar 2) di Bali bagian Tengah vegetasi tumbuhan pakandidominasioleh:Paspalumconjugatum,Cynodon dactylon, Apluda, Pennisetum purpureum, Eleucine indica, Digitaria, Imperata cylindrica, Leptochloa, 
Axonopus compresus, Oplismenus burmanii, Polytrias amaura, Mikania cordata, Panicum repens, Lersia hexandra, dan Erythrina lithosperma.

Di Bali Bagian Timur yang meliputi Desa Kubu, Tianyar Barat, Abang, Tulamben, Bonyoh, Ban, Seraya (Gambar 3), vegetasi tumbuhan pakan didominasi oleh: Hyparrhenia rufa, Cyperus rotundus, Ischaenum timorensis, Alysicarpus vaginalis, Pennisetum purpureum, Centrosema pubescens, Killinga monocephala, Cirtococcum, Paspalum conjugatum, Brachiaria reptans, Imperata cylindrica, Panicum repens, dan Eragrotis amabilis.

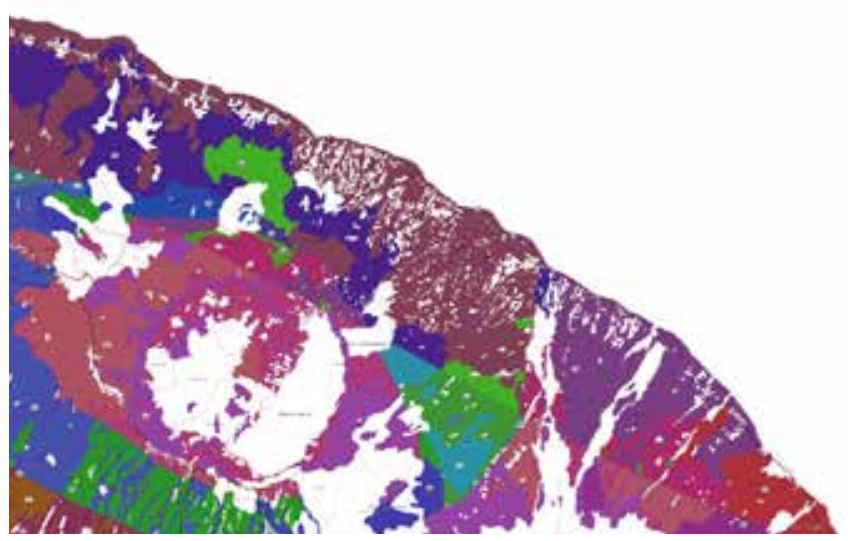

Gambar 3. Hamparan lahan dengan vegetasi tumbuhan pakannya

Di Desa Rendang, Pempatan vegetasi tumbuhan pakan didominasi oleh: Ischaenum timorensis, Pennisetum purpureum, Pennisetum purpupoides, Paspalum conjugatum, Polytrias amaura, Panicum repens, Lersia hexandra, Paspalum conjugatum, Cynodon dactylon, Eleucine indica, Mikania cordata, Albizzia chinensia Merr, Fucus firtulosa Reinw, Erythrina variagata, Fucus variagata B.L., Caliandra callotirsus, dan Molochia umbellate.

Di Bali Selatan bagian barat antara lain di Desa Perancak, Yeh Kuning, Pekutatan, Lalanglinggah, Selemadeg, Tegal Mengkeb dan Sudimara (Gambar 4) vegetasi tumbuhan pakan didominasi oleh: Stenotaphrum secundatum, Macroptilium lathyroides, Caliandra callotirsus, Gliricidia sepium, Pennistum purpureum, Lersia hexandra, Mikania cordata, Paspalum conjugatum, Desmodium, Lersia hexandra, Erythrina sumbumbrant, Azadirachta indica Juss, Lannea corromandilaca Merr, Erythrina orientalis, Centrosema pubescens, Eragrotis amabilis amabilis, Ipomoea batatas, Zoysea matrella, dan Leucaena leucocephala.

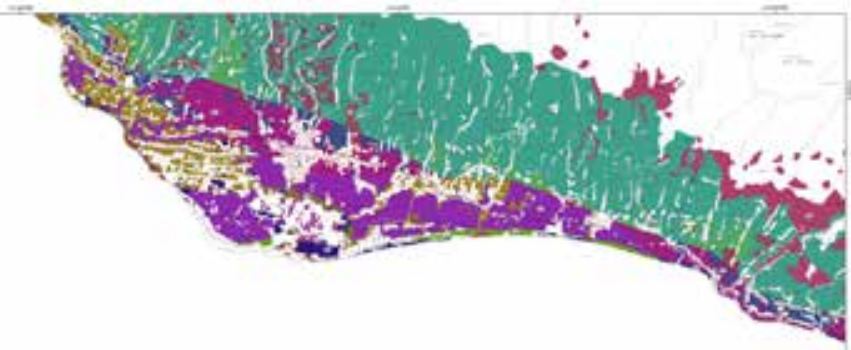

Gambar 4. Hamparan lahan tumbuhan pakan di wilayah Bali bagian selatan

Di Bali Tengah Bagian Selatan antara lain di Desa Darmasaba, Sibang Gede, Kedewatan, Ubud, Peguyangan, Petang, Pelaga, Payangan, Melinggih, Peliatan, Kemenuh, Bedulu, Pejeng (Gambar 5). dan Sukawati vegetasi tumbuhan pakan didominasi oleh: Pennisetum purpureum, Pennisetum purpupoides, Calopogonium muconoides, Centrosema pubescens, Paspalum conjugatum, Cynodon dactylon, Eleucine indica, Digitaria, Imperata cylindrical, Leptochloa, Axonopus compresus, Polytrias amaura, Mikania cordata, Panicum repens, dan Lersia hexandra.

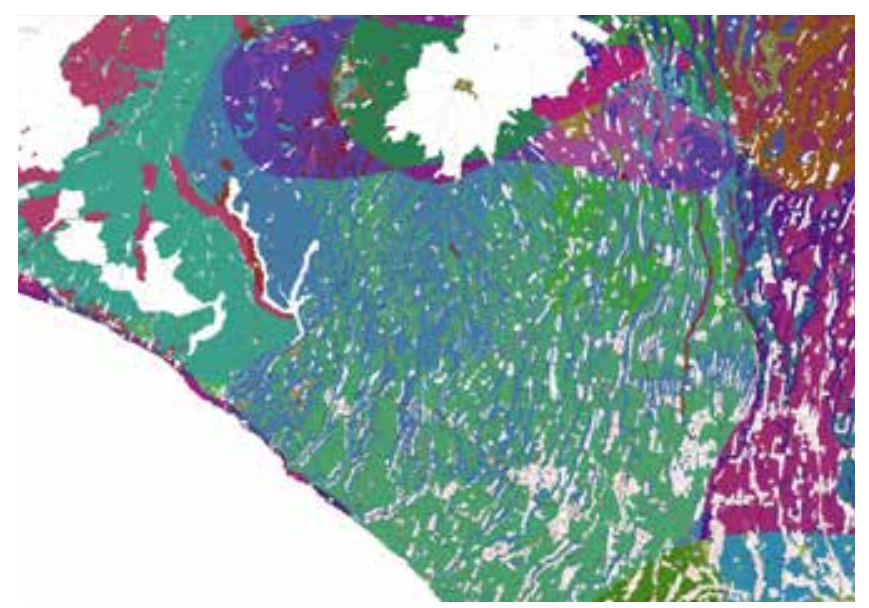

Gambar 5. Hamparan vegetasi hijauan di Selatan Bali bagian Tengah

Bali bagian Selatan yang meliputi desa-desa Kuta Selatan, Serangan, Sanur, Denpasar Selatan, Kesiman Petilan, Padang Sambian dan Kuta Utara vegetasi tumbuhan pakan didominasi oleh: Leucaena leucocephala, Gliricidia sepium, Urochloa mosambicensis, Panicum maksimum, Cenchrus ciliaris, Heteropogon contortus, Polytrias amaura, Bothreochloa, Chloris barbata, Steno lokal, Ageratum conyzoides, Killinga monocephala, Echinochloa, Synedrella, Cassia, dan Commelina diffusa. 


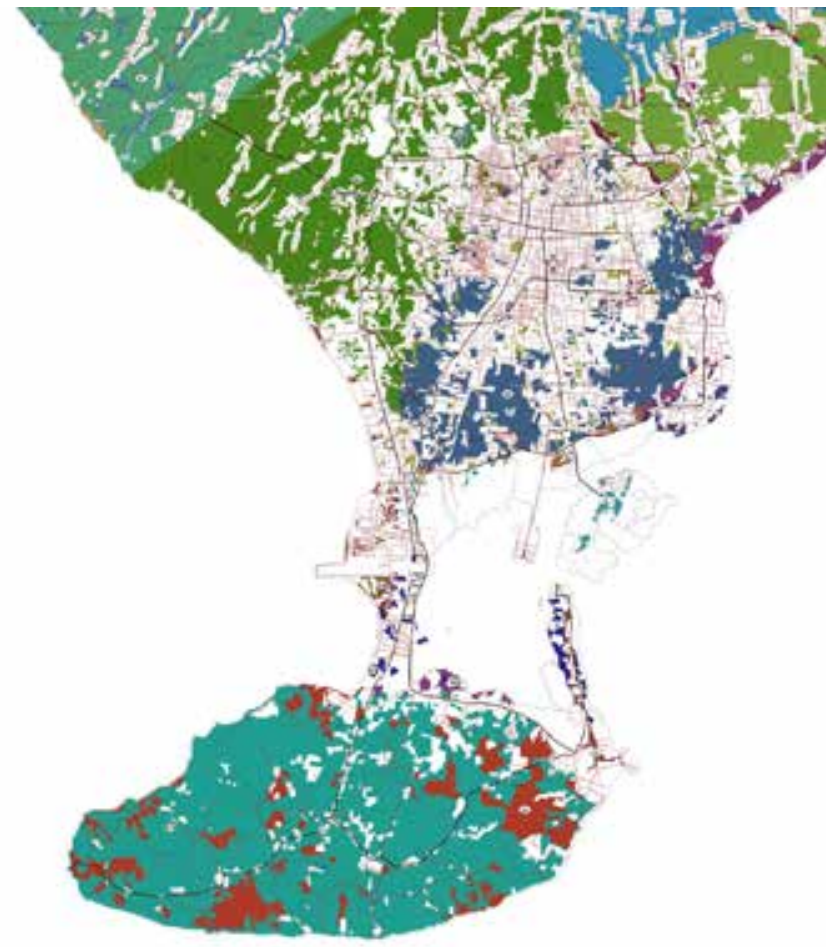

Gambar 6. Hamparan lahan pengembangan peternakan

Bali Tengah Selatan Bagian Timur antara lain meliputi Blahbatuh, Gianyar, Tampaksiring, Bangli, Kintamani, Klungkung, Manggis, Duda, dan Karangasem (Gambar 7). vegetasi tumbuhan pakan didominasi oleh: Cynodon dactylon, Panicum maximum, Stenotaphrum secundatum, Digitaria sp, Commelina diffusa, Zoysea matrella, Paspalum conjugatum, Panicum repens, Axonopus compresus, Leptochloa chinensis, Heteropogon contortus, Polytrias amaura, dan Paspalum conjugatum,

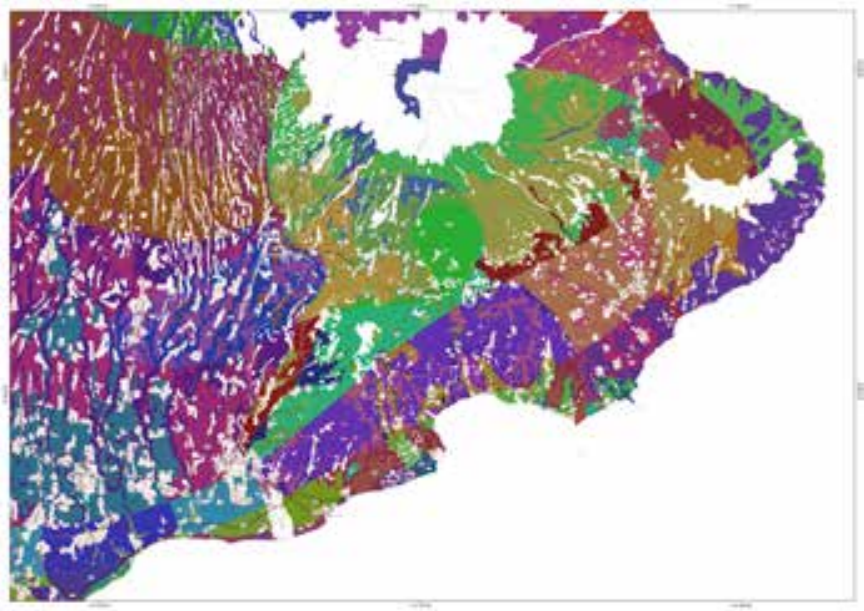

Gambar 7. Hamparan lahan di ujung timur pulau Bali

Di kepeluauan Nusa Penida di Kabupaten Klungkung (Gambar 8) vegetasi tumbuhan pakan didominasi oleh:
Ziziphus yuyuba Lamk, Molochia umbellate, Gliricidia sepium, Sesbania algyptiaca Pers, Malia azedorach L Sandoricum kucape Merr, Hibiscus rosasinensis, Moringa oleifera Lamk, Calliandra eryophila, dan Leucaena leucocephala.

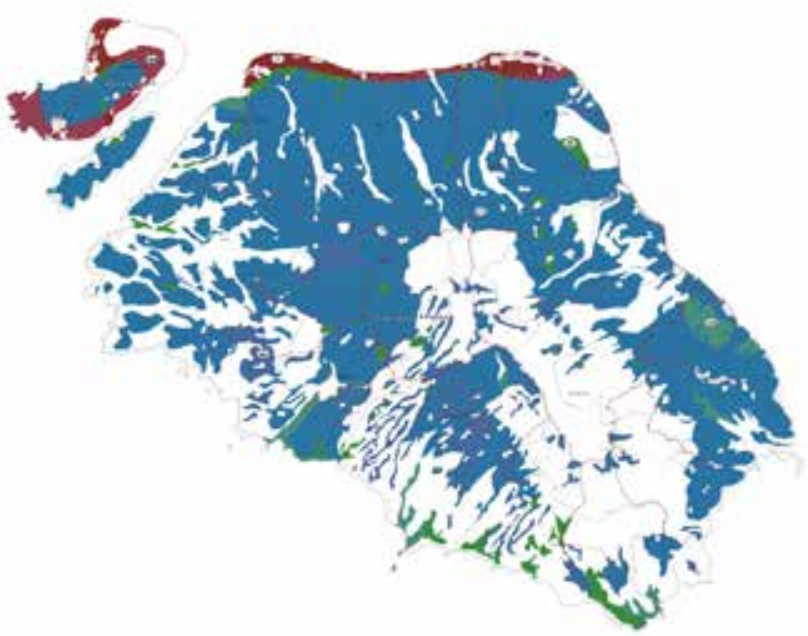

Gambar 8. Hamparan padang rumput di Nusa Penida
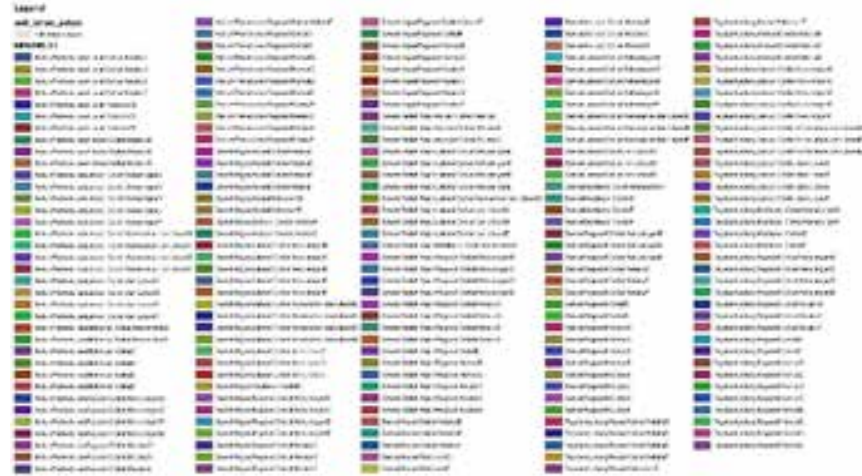

Kualitas Hijauan Tumbuhan Pakan Lokal di Bali

Ketersediaan hijauan pakan baik kuantitas maupun kualitasnya sangat dipengaruhi oleh berbagai faktor seperti iklim, jenis tanah, tata guna lahan, dan berbagai faktor lainnya. Fluktuasi ketersediaan hijauan pakan merupakan tantangan dalam peningkatan produktivitas ternak ruminansia di daerah tropis. Kualitas kimia hijauan akan menurun drastis ketika musim kemarau sehingga berdampak pada menurunnya tingkat produktivitas ternak, seperti tingginya angka kematian dan rendahnya laju pertumbuhan tanaman. Berberapa jenis TPT yang dianalisis komposisi kimia hijauannya berpotensi dalam penyediaan pakan hijauan yang kualitas nutrisinya baik dan daya adaptasinya yang tinggi terhadap kekeringan. Hal tersebut sesuai dengan hasil penelitian sebelumnya oleh Suarna dan Budiasa (2016). Kualitas hijauuan pakan dapat dilihat dari komposisi kimianya, analisis in-vitro, dan analisis in-vivo. Dalam penelitian ini dilakukan analisis kimia dengan hasil 
Tabel 1. Komposisi Kimia Hijauan Pakan Lokal di Bali

\begin{tabular}{|c|c|c|c|c|c|c|c|c|c|c|}
\hline \multirow{2}{*}{ No. } & \multirow{2}{*}{ Jenis Tanaman Pakan } & $\mathrm{BK}$ & Protein & $\mathrm{GE}$ & SK & Abu & NDF & ADF & $\mathrm{Ca}$ & $\mathrm{P}$ \\
\hline & & $(\%)$ & $(\%)$ & $\mathrm{kcal} / \mathrm{kg}$ & (\%) & $(\%)$ & $(\%)$ & $(\%)$ & $(\%)$ & $(\%)$ \\
\hline 1 & Acacia villosa & 16,35 & 10,66 & 3461 & 37,66 & 16,38 & 63,58 & 43,58 & 0,23 & 0,25 \\
\hline 2 & Ageratum & 11,33 & 9,76 & 3448 & 37,27 & 16,58 & 63,37 & 39,31 & 0,21 & 0,31 \\
\hline 3 & Artocarpus integra Merr & 34,16 & 12,30 & 3522 & 24,15 & 16,48 & 54,78 & 47,33 & 1,08 & 0,18 \\
\hline 4 & Astimesia vulgaris & 20,61 & 14,42 & 3481 & 28,96 & 13,75 & 51,75 & 48,87 & 0,73 & 0,13 \\
\hline 5 & Asystasia gangetica & 18,40 & 19,73 & 3978 & 18,68 & 9,37 & 40,40 & 33,58 & 0,26 & 0,14 \\
\hline 6 & Axonopus compresus & 14,86 & 15,86 & 3405 & 19,97 & 15,38 & 40,52 & 28,86 & 0,98 & 0,41 \\
\hline 7 & Botriochloa ischainum & 19,77 & 7,98 & 3295 & 31,09 & 18,06 & 68,51 & 43,43 & 0,09 & 0,22 \\
\hline 8 & Brachiaria decumbens & 23,22 & 9,19 & 3396 & 27,78 & 16,74 & 63,18 & 38,44 & 1,51 & 0,37 \\
\hline 9 & Brachiaria reptans & 15,12 & 24,76 & 3711 & 30,82 & 13,04 & 46,90 & 37,65 & 0,65 & 0,35 \\
\hline 10 & Centrosema pubescens & 16,15 & 22,08 & 3750 & 46,82 & 13,05 & 47,91 & 42,97 & 0,87 & 0,36 \\
\hline 11 & Crotalaria striata & 28,96 & 27,53 & 3927 & 30,76 & 8,45 & 47,26 & 37,11 & 0,45 & 0,31 \\
\hline 12 & Crotalaria usaramoensis & 19,06 & 26,12 & 4094 & 29,86 & 7,78 & 52,72 & 38,37 & 0,25 & 0,31 \\
\hline 13 & Cyrtococcum & 17,21 & 22,35 & 3972 & 24,41 & 7,07 & 54,48 & 42,53 & 0,74 & 0,22 \\
\hline 14 & Debelgia satifolia Roxb & 16,67 & 18,01 & 3607 & 27,50 & 10,86 & 49,75 & 40,72 & 0,63 & 0,16 \\
\hline 15 & Desmanthus virgatus & 32,28 & 10,53 & 3406 & 27,86 & 16,64 & 66,71 & 40,81 & 0,19 & 0,26 \\
\hline 16 & Desmodium sp & 19,22 & 17,51 & 3236 & 26,01 & 19,00 & 41,88 & 35,58 & 0,08 & 0,39 \\
\hline 17 & Digitaria & 20,02 & 11,19 & 3624 & 27,49 & 15,87 & 52,36 & 36,02 & 0,37 & 0,21 \\
\hline 18 & Eriochloa procera & 15,33 & 7,19 & 3395 & 28,00 & 16,00 & 66,62 & 40,49 & 1,72 & 0,27 \\
\hline 19 & Erythrina lithosperma Miq & 33,51 & 16,62 & 3085 & 26,11 & 23,17 & 66,85 & 52,72 & 2,70 & 0,33 \\
\hline 20 & Ficus montana & 17,99 & 14,05 & 3194 & 29,18 & 21,09 & 48,02 & 45,08 & 2,24 & 0,20 \\
\hline 21 & Fucus firtulosa Reinw & 17,79 & 10,14 & 3327 & 28,82 & 18,94 & 63,02 & 45,19 & 0,15 & 0,31 \\
\hline 22 & Galing-galing & 15,17 & 14,63 & 4020 & 30,00 & 6,23 & 65,61 & 50,37 & 0,05 & 0,22 \\
\hline 23 & Hibisus tillaceus $\mathrm{L}$ & 19,03 & 15,62 & 3750 & 31,02 & 12,06 & 50,15 & 41,95 & 0,63 & 0,23 \\
\hline 24 & Indigofera arecta & 21,84 & 25,61 & 3700 & 20,17 & 13,08 & 40,43 & 37,35 & 1,53 & 0,35 \\
\hline 25 & Kesegseg & 21,65 & 22,14 & 3869 & 39,51 & 12,24 & 42,79 & 37,98 & 0,54 & 0,23 \\
\hline 26 & Lannea corromandilaca Merr & 27,12 & 28,58 & 4337 & 26,26 & 7,10 & 58,86 & 44,18 & 0,68 & 0,17 \\
\hline 27 & Lersia hexandra & 25,26 & 11,61 & 3267 & 26,63 & 20,97 & 63,99 & 37,28 & 0,07 & 0,38 \\
\hline 28 & Macroptilium lathyroides & 15,58 & 21,22 & 3831 & 29,57 & 11,27 & 54,28 & 39,50 & 0,59 & 0,25 \\
\hline 29 & Moringa oleifera Lamk & 18,98 & 19,21 & 3560 & 27,14 & 15,21 & 35,55 & 27,77 & 1,35 & 0,36 \\
\hline 30 & Panicum maximum & 17,74 & 5,04 & 3529 & 29,43 & 10,27 & 75,66 & 41,34 & 0,23 & 0,22 \\
\hline 31 & Paspalidium desertorum & 17,04 & 9,57 & 3327 & 28,90 & 14,99 & 62,46 & 37,97 & 0,09 & 0,35 \\
\hline 32 & Paspalum comersonii & 18,42 & 17,97 & 3302 & 31,04 & 16,94 & 48,16 & 44,24 & 0,49 & 0,46 \\
\hline 33 & Paspalum conyugatum & 34,74 & 8,97 & 3517 & 37,17 & 13,89 & 64,43 & 37,34 & 0,78 & 0,46 \\
\hline 34 & Pennisetum purpureum & 10,88 & 14,60 & 3652 & 18,99 & 16,57 & 35,52 & 33,62 & 0,59 & 0,39 \\
\hline 35 & Phaseolus lunatus & 20,87 & 8,66 & 3197 & 28,64 & 19,71 & 58,02 & 41,45 & 0,03 & 0,41 \\
\hline 36 & Psopocarpus & 25,23 & 20,65 & 3961 & 13,15 & 9,75 & 56,85 & 42,26 & 0,83 & 0,36 \\
\hline 37 & Pueraria phaseoloides & 16,04 & 6,55 & 3659 & 33,46 & 12,25 & 72,07 & 43,99 & 0,15 & 0,21 \\
\hline 38 & Sesbania grandiflora & 8,27 & 15,63 & 3752 & 14,77 & 11,09 & 61,23 & 54,29 & 0,36 & 0,18 \\
\hline 39 & Setaria splendida & 24,68 & 8,55 & 3345 & 31,63 & 17,31 & 60,59 & 40,82 & 0,03 & 0,32 \\
\hline 40 & Sporobolus africanus & 26,26 & 25,41 & 4136 & 28,52 & 7,65 & 45,99 & 35,62 & 0,36 & 0,14 \\
\hline 41 & Synedrilla nodiflora & 32,69 & 15,77 & 2996 & 17,66 & 21,98 & 50,44 & 40,36 & 1,56 & 0,45 \\
\hline 42 & Zizinhus yuyuba Lamk & 32,78 & 28,34 & 4033 & 20,67 & 11,58 & 50,61 & 24,85 & 0,81 & 0,13 \\
\hline 43 & Zoysea matrella & 33,53 & 7,19 & 3579 & 24,76 & 14,63 & 67,21 & 41,92 & 0,22 & 0,23 \\
\hline
\end{tabular}

sebagaimana tercantum pada Tabel 1. Beberapa TPT memiliki kandungan protein kasar di atas 18\% seperti: Brachiaria reptans, Centrosema pubescens, Crotalaria striata, Crotalaria usaramoensis, Cyrtococcum, Clitoria ternatea, Debelgia satifolia Roxb, Lannea corromandilaca Merr, Macroptilium lathyroides, Moringa oleifera Lamk, Sporobolus africanus, dan Zizinhus yuyuba Lamk.

\section{Produksi Biomasa Hijauan Pakan}

Biomassa adalah jumlah bahan organik yang diproduksi organisme (tumbuhan) per satuan unit area pada suatu waktu. Biomassa biasanya dinyatakan dalam ukuran berat kering, dalam gram atau kalori, dengan unit satuan biomassa adalah gram per $\mathrm{m}^{2}(\mathrm{~g}$ $\left.\mathrm{m}^{-2}\right)$ atau $\mathrm{kg}$ per hektar $\left(\mathrm{kg} \mathrm{ha}^{-1}\right)$ atau ton per hektar. Brown (1997) mendefinisikan biomassa sebagai jumlah nilai bahan organik yang hidup di atas permukaan tanah pada pohon termasuk daun, ranting, cabang, dan batang utama yang dinyatakan dalam berat kering oven ton per unit area.

Biomassa tersusun oleh senyawa karbohidrat yang terdiri dari elemen karbon, hidrogen, dan oksigen yang dihasilkan dari proses fotosintesis tanaman. Kandungan biomassa pada tiap-tiap bagian pohon berbeda misalnya pada pohon komersil umumnya terdiri dari batang pohon (6o-65\%), tajuk (5\%), daun dan cabang (10-15\%) dan akar (5\%). Pada bagian batang memiliki komposisi 
selulosa 50\%, hemiselulosa 20\%dan lignin 30\% (White dan Plaskett, 1981). Biomassa dalam hutan merupakan selisih antara hasil fotosintesis dengan konsumsi untuk respirasi dan proses pemanenan (Whitten et al. 1984). Biomassa dari sampah dan bibit tanaman di bawah dengan menggunakan Standar Nasional Indonesia diperkirakan nilai karbon yang tersimpan adalah 0,47 dari biomassa.

Pada Tabel 2 terlihat bahwa produksi biomassa rata-rata tanaman pakan di Bali adalah $1239,76 \mathrm{~kg}$ $\mathrm{DM} \mathrm{ha}{ }^{-2}$ sedangkan rata-rata produksi atau cadangan karbon adalah $582,687 \mathrm{~kg} \mathrm{DM} \mathrm{ha}^{-2}$. Berdasarkan nilai tersebut dapat dikatakan bahwa simpanan karbon yang ada pada hijauan pakan ternak adalah cukup tinggi. Jika luasan seluruh unit lahan yang potensial ditanami hijuan pakan adalah 383991,642 ha, maka produksi biomassa dari hijauan pakan adalah sebesar 476.057,27 ton dan simpanan karbonnya mencapai 223.746.92 ton. Kenyataan ini menggambarkan bahwa tutupan vegetasi oleh tumbuhan pakan memiliki peran yang sangat penting sebagai salah satu upaya untuk meningkatkan serapan karbon dalam program mitigasi perubahan iklim (Suarna, 2011).

Tabel 2. Produksi biomassa dan simpanan karbon pada tanaman pakan

\begin{tabular}{|c|c|c|}
\hline No & Tata Guna Lahan & Hijauan kg DM ha-2 \\
\hline 1 & Pastura alam & 214,414 \\
\hline 2 & Kebun TPT & 871,123 \\
\hline 3 & Kebun/tegalan & 0,862 \\
\hline 4 & Pohon & 2,099 \\
\hline \multirow[t]{3}{*}{5} & Semak & 151,261 \\
\hline & Total Biomassa & 1239,759 \\
\hline & Total karbon & 582,687 \\
\hline
\end{tabular}

\section{SIMPULAN}

Dapat disimpulkan bahwa beberapa tumbuhan pakan dapat hidup pada berbagai wilayah dan kondisi klimatologis yang ada di Bali, namun perbedaan topografi dan tipologi tataguna lahan juga memunculkan beberapa tumbuhan pakan yang sangat spesifik ada pada wilayah tertentu sesuai dengan persyaratan tumbuh tanaman tersebut. Produksi biomassa hijauan pakan di Bali cukup tinggi yakni mencapai sebesar 476.057,27 ton dan simpanan karbonnya mencapai 223.746.92 ton. Jenis tanaman yang akan diuji antara lain: Jenis rumput: Hyparhaenia rupa, Heteropogon contortus, Oplismenus burmanii, dan Axonopus compresus; Jenis legum: Clitoria ternatea, Centrosema pubescens, Alysicarpus vaginalis, dan Macroptilium lathyroides; jenis herba lainnya adalah Mikania cordata dan Asystasia gangetica.

\section{UCAPAN TERIMAKASIH}

Penulis mengucapkan terimakasih kepada Kementerian Riset, Teknologi, dan Pendidikan Tinggi atas fasilitasi pendanaan riset ini melalui Kontrak Penelitian Nomor: 415.35/UN14.4.A/PL/2O17 dan 171.115/UN14.4.A/LT/2O18. Terimakasih pula kepada Rektor Universitas Udayana, Ketua LPPM Universitas Udayana serta kepada seluruh Staf Pusat Penelitian dan Pengembangan (Puslitbang) Tumbuhan Pakan Univesitas Udayana, Laboratorium Nutrisi Fakultas Peternakan Universitas Udayana atas bantuan dan dukungannya.

\section{DAFTAR PUSTAKA}

Artise H.S. Salendu dan Femi H. Elly. 2014. Potensi Pengembangan Hijauan Pakan Ternak Sapi di Bawah Pohon Kelapa di Kecamatan Lolayan Kabupaten Bolaang Mongondow. J. Pastura. 4 (1) : 7-10.

As-syakur, A. R., I W. Suarna, I W. Rusna, dan I N. Dibia. 2011. Pemetaan Kesesuaian Iklim Tanaman Pakan serta Kerentanannya Terhadap Perubahan Iklim dengan Sistem Informasi Geografi (SIG) Di Provinsi Bali. J. Pastura 1(1): 9 - 15.

Brown, S. 1997. Estimating Biomass and Biomass Change of Tropical Forests. FAO FORESTRY PAPER. Department of Natural Resources and Environmental SciencesUniversity of Illinois, Urbana, Illinois, USA.

Distan Bali. 2010. Kegiatan Sistem Pertanian Terintegrasi (Simantri) di Provinsi Bali. Dinas Pertanian Tanaman Pangan Provinsi Bali, Denpasar.

Ginantra, K., Sentana Putra, Wayan Suarna, and Wayan Kasa. 2014. Botanical Composition of Forage by Timor Deer (Cervus timorensis Blainville) in a Monsoon Forest and Savanna of West Bali National Park. International Journal of Pure \& Applied Bioscience (IJPAB). 2 (5): 205-213 (2014).

Kesumadewi, AAI., M. Sudana, M. Adnyana, and W. Suarna. 2015. Prediction of The Effect of Deforestation Followed by Intensive Vegetables Cropping Systems on Populaton Density and invitro Ability of Phosphorhizobaceria in Tropical Highland of Bali Island, Indonesia. Int.J.Curr. Microbiol. App. Sc. 4 (4): $685-700$.

Lakitan, B. 2002. Dasar-Dasar Klimatologi. PT RajaGrafindo Persada. Jakarta.

Suarna, I W. dan I K. M. Budiasa. 2016. Pengaruh pupuk organic terhadap produksi dan kualitas hijauan pasture campuran pada lahan kering di desa Sebudi Karangasem. Majalah Ilmiah Peternakan. Vol. 19 No. 3: 125-128. 
Suarna, I W. dan N.N. Suryani. 2013. Potensi dan Pengembangan Tanaman Pakan pada Lahan Perkebunan di Kabupaten Gianyar Provinsi Bali. Prosiding Semnas II HITPI di Denpasar.

Suarna, I W., I K. M. Budiasa, I W. Wirawan, dan N. L. G. Sumardani. 2014. Daya Dukung Lahan dan Tumbuhan Pakan dalam Pengembangan Komuditas Unggulan Peternakan di Kabupaten Gianyar. J. Pastura 4(1): 51-55.

Suarna, I W., M.A.P. Duarsa, N.P. Mariani, L.G. Sumardani, dan S.A. Lindawati. 2016. Daya Dukung Hijauan Pakan Dalam Konservasi Sapi Putih Taro. Jurnal Bumi Lestari. 16 (1): 38-43.

Suarna, W. 2011. Peran Tanaman Pakan Dalam Mitigasi Dan Adaptasi Terhadap Perubahan Iklim. Prosiding
Seminar dan Lokakarya Nasonal Tanaman Makanan Ternak Tropik. Fakultas Peternakan Universitas Udayana, Denpasar.

Sudirman1, Gde Mertha dan Suhubdy. 2014. Inventarisasi Hijauan Pakan Kuda Pacuan di Nusa Tenggara Barat. J. Pastura. 3(2) : 99-101.

Suhubdy Y. 2013. Perilaku Makan Ruminansia sebagai Bioindikator Fenologi dan Dinamika Padang Penggembalaan. J. Pastura 3(1): 1-4.

t'Mannetje, L. And Haydock, KP. (1963). The dry weight rank method for the botanical analysis of pasturfe. Br. Gratsh. Soc. 18:268

Taufan P. Daru, Arliana Yulianti, dan Eko Widodo. 2014. Potensi Hijauan di Perkebunan Kelapa Sawit sebagai Pakan Sapi Potong di Kabupaten Kutai Kartanegara. J. Pastura 3(2): 94-98 